\title{
Effects of Economic Growth, Trade Openness, and Urbanization on Carbon Dioxide Emissions in Ghana, 1960 to 2014
}

\author{
Forster Kwame Boateng ${ }^{1}$ \\ ${ }^{1}$ West Africa Regional Head, Alliance for Green Revolution in Africa (AGRA), Accra, Ghana \\ Correspondence: Forster Kwame Boateng, West Africa Regional Head, Alliance for Green Revolution in Africa \\ (AGRA), Accra, Ghana.
}

Received: December 31, 2019

Accepted: January 27, $2020 \quad$ Available online: February 10, 2020

doi:10.11114/aef.v7i2.4710

URL: https://doi.org/10.11114/aef.v7i2.4710

\begin{abstract}
This paper examines the effects of per capita gross domestic product (GDP), trade openness, and urbanization on the total carbon dioxide emissions of Ghana using time-series annual data from 1960 to 2014. The 55-year period, from 1960 to 2014, covered economic transformation of Ghana from a low-income agrarian country to a lower-middle income country. The analysis used the autoregressive distributed lag method of co-integration. The results showed that per capita GDP, trade openness, and urbanization all significantly influenced both long-run and short-run levels of carbon dioxide emissions in Ghana. However, increased trade openness led to reduced total emissions, while rising per capita GDP and increased urbanization both increased total emissions albeit at different intensity levels.
\end{abstract}

Keywords: Africa, carbon dioxide emissions, congestion goods, environmental economics, Ghana, greenhouse gases, resource economics, sustainable development

\section{Introduction and Problem Statement}

Economic development is a process aimed at achieving increasing per capita national incomes, reducing poverty, improving food security, and national nutrition quality (Mellor, 2017). Economic growth is one key measure of a country's human development. However, the singular pursuit of economic growth objective is likely to exhaust a country's stock of natural resources. Unfortunately, this has been the trajectory for many economies in their pursuit to achieve economic growth by transforming renewable resources into non-renewable ones. Rapid industrialization, coupled with globalization and market integration, is characterized by negative externalities such as increased emissions of greenhouse gases, and production of non-degradable waste materials including nuclear wastes.

The pursuit of economic growth worldwide by human beings has resulted in rapid urbanization, industrialization and agricultural operations that are responsible for environmental degradation and pollution (Kijima et al., 2010). Reductions in environmental degradation and pollution are a sine qua non for sustainable development of any economy (Khan and Ullah, 2019). Among the greatest challenges facing humanity in the 21st Century is the extensive environmental degradation and pollution induced by increasing greenhouse gas emissions. Existing literature, (for example, those produced by Khan and Ullah 2019; Haigh, 2017; Li and Yang, 2016; Ramachandra et al. 2015; Abas and Khan, 2014; Gholipour, 2013; Karl and Trenberth, 2003), suggests that that greenhouse gases (GHG) emissions underpin global warming and climate change. GHGs comprise; carbon dioxide, ozone, methane, nitrous oxide, and water vapour. However, carbon dioxide emission is the principal GHG and a major cause for climate change and global warming (Khan and Ullah, 2019). The concentration of carbon dioxide emissions increased by $42 \%$ between 1990 and 2014 (Aung et al., 2017). The significant increase of carbon dioxide concentration in the atmosphere is mainly as a result of combustion of fossil fuels, industrial production and large-scale tropical deforestation (Sokolov et al., 2017). Time series on carbon dioxide emissions from fossil fuels go as far back in 1751 (Boden et al., 2011). Over the last 150 years, anthropogenic activities have accounted for almost all the increase in carbon dioxide emissions (O'Neill et al., 2017; Minx et al., 2017).

The main objective of this study is to examine the relationship between economic growth and total carbon dioxide emissions in Ghana based on evidence generated by the available microdata. The analysis is based on time-series annual data from 1960 to 2014 employing econometric analysis using the cointegration procedure. The effects of real GDP, trade openness, and the intensity of urbanization on total carbon dioxide emissions in Ghana are analysed. The rest of 
the paper is organized as follows: the next section, section two provides a brief description of the study area, Ghana. Section three provides the theoretical framework including the relevant literature review while the fourth section is devoted to the methodology employed by the study. The results of the study are provided in Section five. The final and the sixth component of the paper deal with the conclusions and some policy recommendations.

\section{Profile of the Study Area}

Ghana is an English-speaking nation state in West Africa with a population of about 30 million, growing at an annual rate of 2.5\% based on projections of the 2010 Population and Housing Census (Ghana Statistical Service, 2013). The country shares borders with Togo in the east, La Cote d'Ivoire in the west, Burkina Faso in the north, and in the south, the Atlantic Ocean. Agriculture is an important economic sector employing about $42 \%$ of the population and accounting for about $20 \%$ of the country's GDP over the last decade (2010 to 2019). The major export commodities of the country are based on natural resources. These are cocoa, gold and more recently crude oil, starting from 2011.

In particular, exports of crude oil and the production of natural gas have helped to accelerate economic growth over the last three years. The expansion of the Ghanaian economy coupled with rapid population growth and urban human settlement pressures, have led to a notable GHG emission increases from road transport, thermal electricity generation, biomass utilization for cooking and deforestation. Carbon dioxide remained the dominant GHG in Ghana and constituted about $66 \%$ of the total net emissions levels for 2016 (Ghana GHG Inventory Report 2019). The key drivers of GHG emissions in Ghana are; population growth, carbon-intensive economic growth and diversification, deforestation and road transportation, electricity generation and solid waste disposal. Road transport represents over 95\% of all transport services in Ghana (Simons et al., 2018). Further, over 70\% of Ghana's major roads are occupied by vehicles that produce high amount of exhaust emissions (Adu-Kumi, 2012), thereby increasing the percentage of $\mathrm{CO}_{2}$ in the air and decreasing the air quality.

Figure 1 shows the projected growth of total greenhouse gas emissions in Ghana till 2030. With a projected average population growth rate of $2.4 \%$ per annum and 7\% average GDP growth rate in the period 2016-2030, the country's emissions are expected to increase from 42.2MtCO2e in 2016 to $48 \mathrm{MtCO} 2 \mathrm{e}$ in 2020 to $59.1 \mathrm{MtCO} 2 \mathrm{e}$ in 2025 and further to $73.3 \mathrm{MtCO}$ e in 2030 (Ghana GHG Inventory Report 2019) if no deliberate actions are taken to curb the emissions.

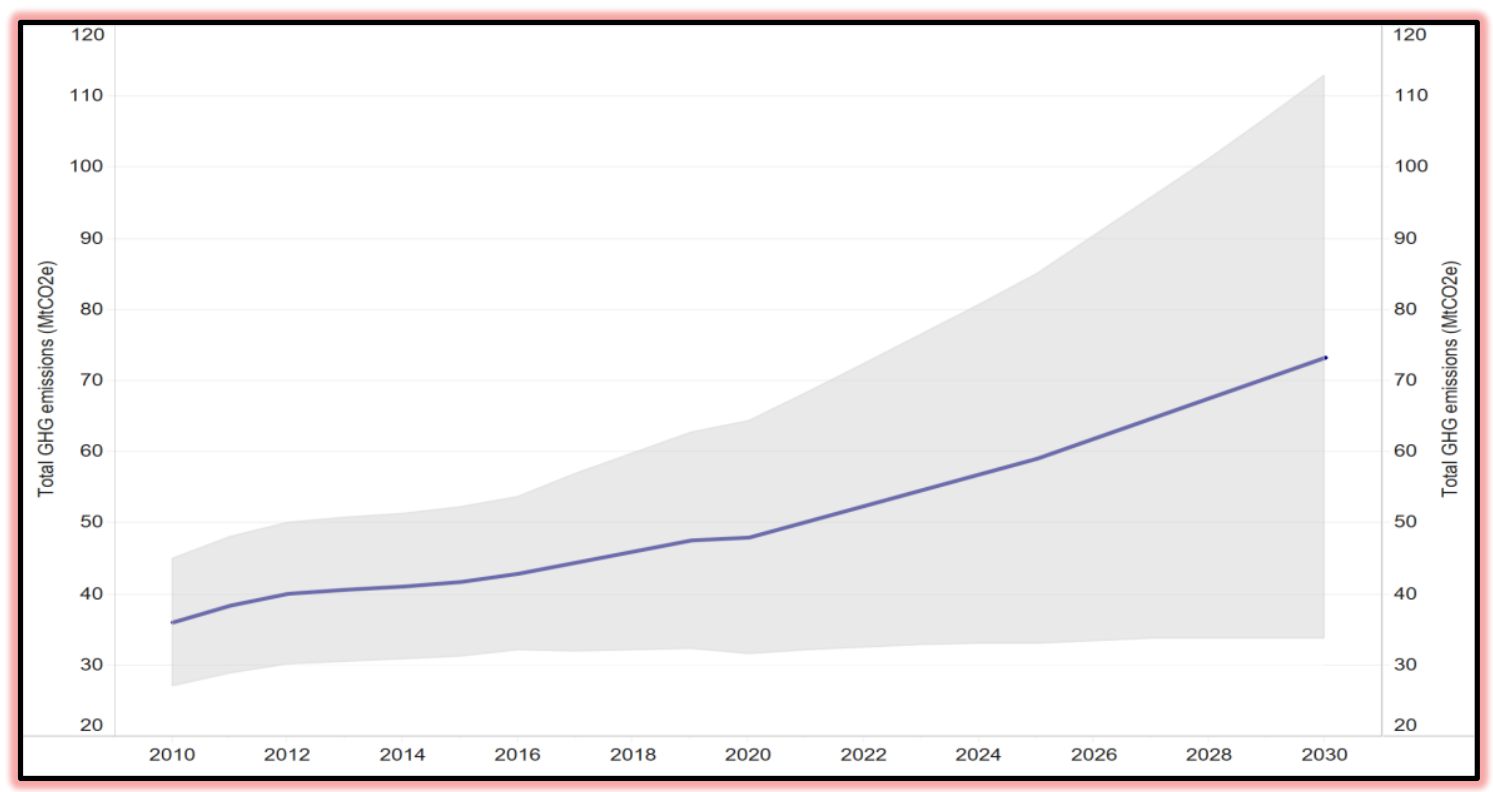

Figure 1. Projected Emission Trajectory up to 2030 showing the uncertainty band

Source: Ghana’s Fourth National Greenhouse Gas Inventory Report, February 2019.

\section{Theoretical Framework}

Conceptually, as shown in Figure 2, the natural environment was initially considered as indivisible and non-exclusive good, a pure public good, that is open to all human beings to use without any effect on the carrying capacity of the environment. This characteristic is exhibited from point $\mathrm{O}$ to point $\mathrm{B}$. The use of the good by one individual does not diminish its quantity and quality to other human beings. Further, the marginal cost of providing any pure public good is zero. With the growing pressures on the environment due to increasing human activities linked to expanding economic growth, environmental resources have become congestion goods. Congestion goods are non-excludable and open to all 
human beings to use. However, positive marginal costs are incurred in accessing these goods. Congestion goods are illustrated in Figure 2 from point $\mathrm{B}$ to point $\mathrm{C}$. The point $\mathrm{C}$ indicates the carrying capacity of the environment; at this point the environmental asset breaks down and is no longer available for use by human beings.

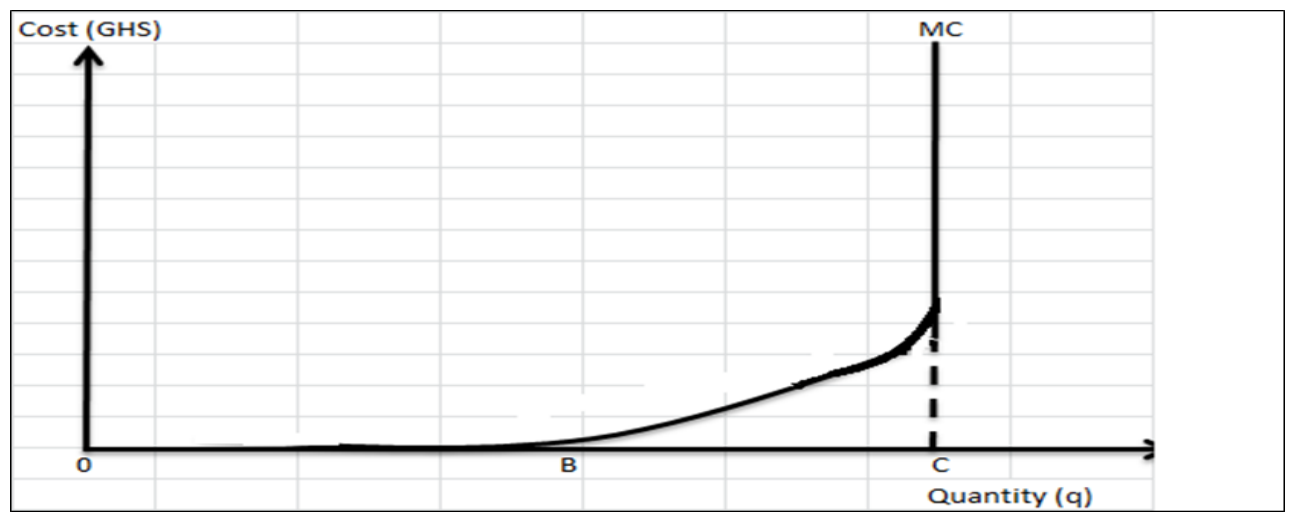

Figure 2. Illustration of the concept of congestion case with the case of the effect of greenhouse emissions on the environment

Overtime, the environment has become increasingly congestible due to increase population growth rate, internal and external migration, economic activities related to domestic production and international trade. Prudent measures therefore ought to be put in place to sustainably manage environment resources, which are largely non-renewable. As countries pursue their economic growth agenda, they are expected to preserve environmental quality, and resources for future use to avoid intergenerational conflict (IGC) in pursuit of their economic growth agenda (Thampapillai et al., 2019)

Introduction of rationing and market instruments is therefore an essential pre-requisite to making environment, which produces quasi-public goods, sustainable for use by both current and future generations with attention paid to management of revenues from these resources, equity, and income distribution issues related to poverty reduction. User cost of non-renewable energy resources for example coal and other fossil fuels, includes depletion of the resources, and the externalities imposed on society (Permian et al., 2003). Even though demand for environmental quality, which directly relate to human health increase with increasing income level, environmental quality indicators do not decrease even at higher income level if environmental problem is as a result of externality (Bo, 2011)

There is a need to embark on sustainable development and not selective policies which seek to address only poverty reduction. From literature, it is evident that a combination of growth and economic imperfections lead to environmental damage and unsustainable outcomes. For the specific case of Ghana, it is important to analyse the key drivers of emissions of greenhouse gases as a first step in deriving sensible policy measures to reduce total emissions and improve the quality of human life by enhancing sustainable development.

\section{Methodology Including Data Sources}

This study was conducted based on hypothesis that the levels of carbon dioxide $\left(\mathrm{CO}_{2)}\right.$ emissions are influenced by trade openness (openness), the degree of urbanization (urbanprop), and per capita GDP (pcrgdp). The data used for the analysis were obtained from several sources. Specifically, the data on carbon dioxide emissions, trade openness and urbanization came from the World Development Indicators publication on Ghana produced by the World Bank. Data on per capita GDP were from Anaman (2018) which assembled economic growth data from 1957 to 2017 using data from the Ghana Statistical Service and the International Financial Statistics produced by the International Monetary Fund. The base year for the macro-economic data was 2006. The earliest and latest years that data on carbon dioxide emissions in Ghana were available from the World Development Indicators were 1960 and 2014 respectively. This factor explained the use of the time period of 1960 to 2014 for the study.

Regression analysis as a statistical method was used to examine the relations between dependent variable and the three variables of interest. The use of regression for the study is consistent with existing literature in the area of environmental economics and international trade that have demonstrated an empirical relationship between the macroeconomy and environmental resource deployment (refer to works such as Grossman and Krueger, 1991; Selden and Song, 1994; Kohler M. 2013, Mizra et.al., 2017; Mikaylov et al. 2018, Khan and Ullah, 2019). The variables used in the econometric analysis are described in Table 1.

The relationship between the actual production levels of carbon dioxide and the three variables of interest is expressed 
in the general production function as follows in Equation 1.

$$
\mathrm{CO}_{\mathrm{t}}=\mathrm{f}\left(\text { Openness }_{\mathrm{t}}, \text { Urbanprop }_{\mathrm{t}}, \text { PCRGDP }_{\mathrm{t}}\right)
$$

Table 1. Description of variables used in the study

\begin{tabular}{|l|l|}
\hline Variable & Description \\
\hline Dependent variable & $\begin{array}{l}\text { Total carbon dioxide emissions measured in kilotons (KT) using data from the World Bank World } \\
\text { Development Indicators database }\end{array}$ \\
\hline $\mathrm{CO}_{2 \mathrm{t}}$ & Total imports and exports divided by the GDP \\
\hline Independent variables & Proportion of population living in urban areas (settlement with population 5,000 or more) \\
\hline Openness $_{\mathrm{t}}$ & Gross Domestic Product per capita measured in GH $\phi$ using real values and 2006 as the base year. \\
\hline Urbanprop $_{\mathrm{t}}$
\end{tabular}

The linear and log-linear forms of the model in Equation 1 are specified in Equations 2 and 3.

$$
\begin{aligned}
& \mathrm{CO}_{2}=\mathrm{A}_{0}+\mathrm{A}_{1} \text { Openness }_{\mathrm{t}}+\mathrm{A}_{2} \text { Urbanprop }_{\mathrm{t}}+\mathrm{A}_{3} \text { PCRGDP }_{\mathrm{t}}+\mathrm{U}_{\mathrm{t}} \ldots \ldots \ldots \ldots \ldots \ldots \ldots \ldots \ldots \ldots \ldots . . . \ldots \text { Equation } 2 \\
& \mathrm{LCO}_{\mathrm{t}}=\mathrm{B}_{0}+\mathrm{B}_{1} \text { LOpenness }_{\mathrm{t}}+\mathrm{B}_{2} \text { LUrbanprop }_{\mathrm{t}}+\mathrm{B}_{3} \text { LPCRGDP }_{\mathrm{t}}+\mathrm{V}_{\mathrm{t}}
\end{aligned}
$$

where LCO2, LOpenness, LUrbanprop, and LPCRGDP are natural logarithms of CO2, Openness, Urbanprop, and PCRGDP respectively; $\mathrm{Ai}$ and $\mathrm{Bi}$ are parameters and $\mathrm{Ut}$ and $\mathrm{Vt}$ are error terms initially assumed to have zero means and constant variances.

The log-linear version of the model was utilized for this study because it was superior to the linear version based on the basic econometric diagnostic tests and the power of the model measured by the $\mathbf{R}^{2}$. The unit root test was applied to each variable in the log-linear function to check the data for stationarity based on the augmented Dickey-Fuller test (ADF) (Dickey and Fuller (1981), and the Phillips-Perron test (PP) (Phillips and Perron, 1988), using the Time Series Processor (TSP) software (Hall and Cummins, 2009). The null hypothesis was that there was a unit root in the time series. The optimal lag length in the model was determined using a model selection criterion based on the Schwarz Bayesian Criterion, similar to the approaches used by Anaman and Mahmod (2003), Junyi (2006), Tiwari et al. (2013), and Khan and Ullah (2019).

Co-integration exists if all the variables in a model (both the dependent and independent variables) have the same order of integration (Engel and Granger (1987). This study employed the autoregressive distributed lag (ARDL) method (bound testing approach) to check for a long-run relationship among the variables in the model. A good attribute of the ARDL method is that it can be applied to the model whether the variables are stationary or non-stationary; further it establishes a maximum of only one long-run co-integration relationship.

The ARDL approach used in this study employs a vector autoregressive (VAR) model that checks for the existence of a long-run relationship between carbon dioxide emission (dependent variable) and the independent variables (Openness, Urbanprop, and PCRGDP). The ARDL method involves the bounds test using a correctly specified model (Pesaran $e t$ al., 2001; Lewis and MacDonald, 2002; Anaman and Mahmod, 2003; and Khan and Ullah, 2019).

For this study, the correctly specified ARDL model was determined by using different diagnostic tests. The Ramsey RESET test (Ramsey 1969) was applied to check specification of the model. In order to check whether the data are normally distributed, the Jarque-Bera test (Jarque and Bera 1987) was used. The Breusch-Godfrey serial correlation test (Breusch 1978; Godfrey 1978) tests was also applied to check that the ARDL model was free from the problem of serial correlation. Then the Langrange-Multiplier (LM) test was used to establish the presence or otherwise of the problem of heteroscedasticity (refer to Pesaran et al., 2001).

The null hypothesis of the bounds test specifies that the coefficients of the lagged terms of the unrestricted error correction model are jointly equal to zero. The existence of a long-run relationship among the variables is proven if the test statistic lies above the upper bound critical value. For this study, the optimal ARDL model is specified as follows in Equation 4.

$$
\mathrm{LCO}_{2 \mathrm{t}}=\mathrm{C}_{0}+\mathrm{C}_{1} \mathrm{LCO}_{2 \mathrm{t}-1}+\mathrm{C}_{2} \text { LOpenness }_{\mathrm{t}}+\mathrm{C}_{3} \text { LUrbanprop }_{\mathrm{t}}+\mathrm{C}_{4} \text { LPCRGDP }_{\mathrm{t}}+\mathrm{W}_{\mathrm{t} .}
$$
Equation 4

The derivation of the long-run relationship is derived once the existence of a long-run relationship among the variables has been confirmed by the ARDL model. The long-run relationship is similar to Equation 3. The error correction model of the derived long-run relationship for this study is shown in Equation 5 where the Ut-1 is the lagged error term from the underlying long-run cointegration relationship.

$$
\mathrm{DLCO}_{2 \mathrm{t}}=\mathrm{E}_{0}+\mathrm{E}_{1} \mathrm{U}_{\mathrm{t}-1}+\mathrm{E}_{2} \mathrm{DLCO}_{2 \mathrm{t}-1}+\mathrm{E}_{3} \text { DLOpenness }_{\mathrm{t}}+\mathrm{E}_{4} \text { DLUrbanprop }_{\mathrm{t}}+\mathrm{E}_{5} \text { DLPCRGDP }_{\mathrm{t}}+\mathrm{Z}_{\mathrm{t} . \ldots \ldots \ldots \ldots . . .} \text { Equation5 }
$$




\section{Results}

The results of the unit root tests are reported in Table 2. For variables at the levels, most of the variables were non-stationary based on both the ADF or PP tests. However, using the first differences, three out of four variables were stationary based on the PP test. These three variables were LCO2, LPCRGDP and LOPENNESS. Hence these variables were integrated of the order I(1). The Urbanprop variable was the only variable not stationary based on its difference. With a combination of stationary and non-stationary variables using different levels of integration, the ARDL cointegration analysis is the ideal tool to derive the long-run relationships between the dependent variable and the independent variables (Pesaran et al., 2001).

The estimated optimal ARDL function is reported in Table 3. The bounds test confirmed that there was a valid cointegration relationship among the dependent variable and the three independent variables. The bounds test $\mathrm{F}$ value was 9.150; this was much greater than the $95 \%$ critical upper bound value of 4.656 . Similarly, the bounds test W value was 36.600; and this value was much greater than the 95\% critical upper bound value of 18.624 . Hence both tests confirmed the rejection of the null hypothesis of no valid cointegration among the variables. The Ramsey RESET test confirmed that the model was correctly specified. There was absence of significant serial correlation based on the Breusch-Godfrey test. There was also no significant heteroscedasticity as indicated by the LM test. The power of the ARDL model was also very high with $\mathrm{R}^{2}$ of 0.975 and adjusted $\mathrm{R}^{2}$ of 0.972 (refer to results in Table 3).

Table 2. Unit root tests of the continuous variables at the levels and first differences

\begin{tabular}{|l|l|l|l|l|}
\hline Variable & ADF Statistic & P Value & PP Statistic & P Value \\
\hline LCO2 $_{\mathbf{t}}$ & -1.770 & 0.791 & -25.616 & $0.022^{* *}$ \\
\hline LPCRGDP $_{\mathbf{t}}$ & -0.388 & 0.987 & -0.161 & 0.996 \\
\hline LURBANPROP $_{\mathbf{t}}$ & -3.399 & $0.052^{*}$ & -4.391 & 0.863 \\
\hline LOPENNESS $_{\mathbf{t}}$ & -1.834 & 0.688 & -7.607 & 0.615 \\
\hline DLCO2 $_{\mathbf{t}}$ & -3.307 & $0.065^{*}$ & -64.410 & $0.000003^{* * *}$ \\
\hline DLPCRGDP $_{\mathbf{t}}$ & -4.017 & $0.008^{* * *}$ & -46.269 & $0.0002^{* * *}$ \\
\hline DLURBANPROP $_{\mathbf{t}}$ & -2.328 & 0.418 & -6.425 & 0.711 \\
\hline DLOPENNESS $_{\mathbf{t}}$ & -3.109 & 0.104 & -32.718 & $0.005^{* * *}$ \\
\hline
\end{tabular}

Notes

D denotes the first difference operator of a variable

*** denotes 1 percent statistical significance

**denotes 5 percent statistical significance

*denotes 10 percent statistical significance

Table 3. Results of the estimated autoregressive distributed lag (ARDL) cointegration model of the production of carbon dioxide (CO2) in Ghana over the period, 1960-2014

Dependent Variable is $\mathrm{LCO}_{\mathrm{t}}(\log$ of total carbon dioxide emissions in Ghana in year $\mathrm{t})$

\begin{tabular}{|l|l|l|l|}
\hline Explanatory variable & $\begin{array}{l}\text { Unstandardized } \\
\text { Parameter estimate }\end{array}$ & Student t-statistic & P value \\
\hline INTERCEPT & -2.426 & 3.736 & $0.000^{* * *}$ \\
\hline LCO2 $_{\mathrm{t}-1}$ & 0.259 & 2.043 & $0.046^{* *}$ \\
\hline LPCRGDP $_{\mathbf{t}}$ & 0.207 & 2.439 & $0.018^{* *}$ \\
\hline LURBANPROP $_{\mathbf{t}}$ & 2.078 & 5.850 & $0.000^{* * *}$ \\
\hline LOPENNESSS $_{\mathbf{t}}$ & -0.065 & -1.999 & $0.051^{*}$ \\
\hline
\end{tabular}

Notes

Sample size 55

$\mathrm{R}^{2}$

$0.975 * * *$

Adjusted $\mathrm{R}^{2}$

$0.973 * * *$

F value

$477.892 * * *$

Probability level of significance of correct specification of the model using

The Ramsey Reset test with null hypothesis of correct model specification

Probability level of significance of the normality of the error term based on 
The Jarque-Bera test with the null hypothesis of normal error term

Probability level of significance of autocorrelation based on the general test of

autocorrelation with the null hypothesis of no autocorrelation

Probability level of significance of the LM test for heteroscedasticity based on

the null hypothesis of homoscedasticity (no heteroscedasticity)

0.458

*denotes 10 percent statistical significance

$* *$ denotes 5 percent statistical significance

***denotes 1 percent statistical significance

The long-run function derived from the estimated ARDL cointegration model are reported in Table 4. The results showed that Trade Openness, Urbanprop, and PCRGDP were all significant in determining the levels of actual carbon dioxide emissions in Ghana. An increase in GDP per capita increases the level of total carbon dioxide emission as expected since increases in national income result in demand for capital goods such as road construction, transportation and others. This finding corroborates other studies conducted by Simons et al. (2018) and Adu- Kumi (2012) that road transport, which represents over $95 \%$ of all transport services, is the biggest contributor to total carbon dioxide emissions in Ghana.

Based on the results shown in Table 4, increased openness led to decreased levels of total carbon dioxide emissions. This factor was due to the utilization of more efficient capital goods used in the construction and other industries. However, increasing urbanization led to increased total carbon dioxide emissions arising from the congestion in urban towns and increased use of transportation services and other sources of carbon-based energy in urban areas. This particular finding related to urbanization is similar to that obtained by Twerefou et al. (2015) for Ghana.

The estimated error correction term for the selected long-run relationship indicate that the error correction term (ECM) was statistically significant. The results of the ECM estimation are presented in Table 5 and indicated that trade openness had a significant negative effect on total carbon dioxide emissions in the short-run period. However, for the same short-run period, urbanization and rising per capita GDP significantly increased the total carbon dioxide emissions. The value of the parameter of error correction term $U_{t-1}$ was -0.741 and was statistically significant. This meant that about $74 \%$ of the discrepancy between the actual value of the dependent variable and the long-run value would be eliminated each year. The statistically-significant error correction term also confirmed that there was a valid cointegration function among the variables.

Table 4. Results of the long-run function derived from estimated autoregressive distributed lag (ARDL) cointegration model of the production of carbon dioxide (CO2) related to a number of variables for Ghana over the period, 1960-2014

Dependent Variable is $\mathrm{LCO} 2_{\mathrm{t}}(\operatorname{logged}$ total carbon dioxide emissions in Ghana in year $\mathrm{t}$ )

\begin{tabular}{|l|l|l|l|}
\hline Explanatory variable & $\begin{array}{l}\text { Unstandardized } \\
\text { Parameter estimate }\end{array}$ & Student t-statistic & P value \\
\hline INTERCEPT & -3.276 & -4.295 & $0.000^{* * *}$ \\
\hline LPCRGDP $_{\mathbf{t}}$ & 0.279 & 2.547 & $0.014^{* *}$ \\
\hline LURBANPOP $_{\mathbf{t}}$ & 2.806 & 26.838 & $0.000^{* * *}$ \\
\hline LOPENNESSS $_{\mathbf{t}}$ & -0.087 & -2.102 & $0.041^{* *}$ \\
\hline
\end{tabular}

\section{Notes}

*denotes 10 percent statistical significance

$* *$ denotes 5 percent statistical significance

***denotes 1 percent statistical significance

Table 5. Results of the estimated error correction function of the production of carbon dioxide (CO2) related to several variables for Ghana over the period, 1960-2014

Dependent Variable is DLCO2 ${ }_{t}$ (the first difference of the logged total carbon dioxide emissions in Ghana for year $t$ )

\begin{tabular}{|l|l|l|l|}
\hline Explanatory variable & $\begin{array}{l}\text { Unstandardized } \\
\text { Parameter estimate }\end{array}$ & Student t-statistic & P value \\
\hline DLPCRGDP $_{\mathbf{t}}$ & 0.207 & 2.439 & $0.018^{* *}$ \\
\hline DLURBANPROP $_{\mathbf{t}}$ & 2.078 & 5.850 & $0.000^{* * *}$ \\
\hline DLOPENNESSS $_{\mathbf{t}}$ & -0.065 & -2.329 & $0.051^{*}$ \\
\hline $\mathbf{U}_{\mathbf{t}-\mathbf{1}}$ (Error Correction Term) & -0.741 & -5.834 & $0.000^{* * *}$ \\
\hline
\end{tabular}

Notes 
Sample size

$\mathrm{R}^{2}$

Adjusted $\mathrm{R}^{2}$

$F$ value

* denotes 10 percent statistical significance

**denotes 5 percent statistical significance

***denotes 1 percent statistical significance
55

$0.418 * * *$

$0.371 * * *$

$8.809 * * *$

\section{Conclusion}

The findings of the research established that for both long-run and short-run periods, the levels of carbon dioxide emissions in Ghana were influenced by trade openness, proportion of population living in urban areas and Gross Domestic Product per capita over the period, 1960 to 2014. Increased trade openness led to decreased total emissions while increasing urbanization and rising GDP per capita increased total emissions. Rising GDP per capita leads to increased average wealth of the country, which then fuels increasing households' consumption demand for luxury goods. For example, the use of private vehicles and increased use of more luxurious residential accommodation by wealthier people lead to increased carbon dioxide emissions.

Further, as more people migrate from the rural areas to urban centres in search for high-paid jobs, increased emissions occur. This phenomenon is due to the increased use of non-renewable resource such as fossil fuels for transportation vehicles affordable by the teeming low-income people. The build-up of carbon dioxide emissions from exhaust fumes of motor-vehicles has serious health implications. In several instances, pollution issues often fall outside the control of individual consumers and firms, therefore measures that deal with pollution, invariably involve some form of public policy interventions.

An important policy measure regarding the use of non-renewable resources pertains to modesty in consumption behaviour. Government should embark on mass transportation policy in the urban areas thus promoting cheaper and efficient public transport and imposing higher taxes on private transport. Metropolitan and Municipal Authorities to enact byelaws to encourage city greening, which could serve as carbon sinks in curbing and reducing greenhouse emissions. Strict enforcement of emission controls is critical to ensuring sustainable development.

\section{Acknowledgments}

I thank Professor Kwabena Asomanin Anaman of the Department of Agricultural Economics and Agribusiness, University of Ghana, Legon, Accra, Ghana for his comments on earlier drafts of this paper. Material support from AGRA, Ministry of Food \& Agriculture-Ghana, and Environmental Protection Agency in Ghana for this study is gratefully acknowledged. Also, I am indebted to Dr. Agnes Kalibata, AGRA President/UN Secretary -General's Special Envoy for the 2021 Food Systems Summitfor her encouragement and time spent in proof reading the final draft of this paper.

\section{References}

Abas, N., \& Khan, N. (2014). Carbon conundrum, climate change, $\mathrm{CO} 2$ capture and consumptions. Journal of $\mathrm{CO}_{2}$ Utilization, 8, 39-48. https://doi.org/10.1016/j.jcou.2014.06.005

Adu-Kumi, S. (2012). Vehicular Emission and Fuel Economy Standards and Enforcement in Ghana. Accra: Ghana Environmental Protection Agency.

Anaman, K. A. (2018). Economic Shocks and Growth in Post-Independence Ghana, 1957 to 2017. Accra, Ghana: Institute for Fiscal Studies.

Anaman, K. A., \& Mahmod, T. H. (2003). Determinants of supply of non-oil exports in Brunei Darussalam. ASEAN Economic Bulletin, 20(2), 144-157. https://doi.org/10.1355/AE20-2D

Aung, T. S., Saboori, B., \& Rasoulinezhad, E. (2017). Economic growth and environmental pollution in Myanmar: an analysis of environmental Kuznets curve. Environmental Science and Pollution Research, 24(25), 20487-20501. https://doi.org/10.1007/s11356-017-9567-3

Bo, S. (2011). A literature survey on environmental Kuznets curve. Energy Procedia, 5, 1322-1325. https://doi.org/10.1016/j.egypro.2011.03.229

Breusch, T. S. (1978). Testing for autocorrelation in dynamic linear models. Australian Economic Papers, 17(31), 334-355. https://doi.org/10.1111/j.1467-8454.1978.tb00635.x

Dickey, D. A., \& Fuller, W. A. (1981). Likelihood ratio statistics for autoregressive time series with a unit 
root. Econometrica, 1057-1072. https://doi.org/10.2307/1912517

Ekins, P. (1995). Rethinking the costs related to global warming: A survey of the issues. Environmental and Resource Economics, 6(3), 231-277.

Engle, R. F., \& Granger, C. W. J. (1987). Co-integration and error-correction: representation, estimation and testing. Econometrica, 55, 255-276. https://doi.org/10.2307/1913236

Ghana's Fourth National Greenhouse Gas Inventory Report (2019). Retrieved from https://unfccc.int/sites/default/files/resource/gh_nir4-1.pdf

Gholipour, F. H. (2013). Foreign direct investments in real estate sector and $\mathrm{CO}_{2}$ emission: Evidence from emerging economies. Management of Environmental Quality: An International Journal, 24(4), 463-476. https://doi.org/10.1108/MEQ-04-2012-0032

Godfrey, L. G. (1978). Testing against general autoregressive and moving average error models when the regressors include lagged dependent variables. Econometrica: Journal of the Econometric Society, 1293-1301. https://doi.org/10.2307/1913829

Grossman, G. M., \& Krueger, A. B. (1991). Environmental Impacts of a North American Free Trade Agreement (No. w3914). Washington, D.C.: National Bureau of Economic Research. https://doi.org/10.3386/w3914

Hall, B. H., \& Cummins, C. (2009). Time Series Processor (TSP) Version 5 Reference Manual. Palo Alto, California: TSP International.

Jarque, C. M., \& Bera, A. K. (1987). A test for normality of observations and regression residuals. International Statistical Review, 55, 163-172. https://doi.org/10.2307/1403192

Junyi, S. (2006). A simultaneous estimation of environmental Kuznets curve: evidence from China. China Economic Review, 17, 383-394. https://doi.org/10.1016/j.chieco.2006.03.002

Karl, T. R., \& Trenberth, K. E. (2003). Modern global climate change. Science, 302(5651), 1719-1723. https://doi.org/10.1126/science.1090228

Khan, D., \& Ullah, A. (2019). Testing the relationship between globalization and carbon dioxide emissions in Pakistan: does environmental Kuznets curve exist? Environmental Science and Pollution Research, 26(15), 15194-15208. https://doi.org/10.1007/s11356-019-04913-9

Kijima, M., Nishide, K., \& Ohyama, A. (2010). Economic models for the environmental Kuznets curve: A survey. Journal of Economic Dynamics and Control, 34(7), 1187-1201. https://doi.org/10.1016/j.jedc.2010.03.010

Kong, Y., \& Khan, R. (2019). To examine environmental pollution by economic growth and their impact in an environmental Kuznets curve (EKC) among developed and developing countries. PloS one, 14(3), e0209532. https://doi.org/10.1371/journal.pone.0209532

Lewis, P. E., \& MacDonald, G. (2002). The elasticity of demand for labour in Australia. Economic Record, 78(240), 18-30. https://doi.org/10.1111/1475-4932.00036

Li, D., \& Yang, D. (2016). Does non-fossil energy usage lower CO2 emissions? Empirical evidence from China. Sustainability, 8(9), 874. https://doi.org/10.3390/su8090874

Lucas, R. E., Wheeler, D., \& Hettige, H. (1992). Economic Development, Environmental Regulation, and the International Migration of Toxic Industrial Pollution, 1960-1988. Washington, D.C.: World Bank Publications.

Mellor, J. W. (2017). Agricultural Development and Economic Transformation: Promoting Growth with Poverty Reduction. London: Springer. https://doi.org/10.1007/978-3-319-65259-7

Mikayilov, J. I., Hasanov, F. J., \& Galeotti, M. (2018). Decoupling of CO2 emissions and GDP: A time-varying cointegration approach. Ecological Indicators, 95, 615-628. https://doi.org/10.1016/j.ecolind.2018.07.051

Minx, J. C., Callaghan, M., Lamb, W. F., Garard, J., \& Edenhofer, O. (2017). Learning about climate change solutions in the IPCC and beyond. Environmental Science \& Policy, 77, 252-259.

https://doi.org/10.1016/j.envsci.2017.05.014

Mirza, F. M., \& Kanwal, A. (2017). Energy consumption, carbon emissions and economic growth in Pakistan: Dynamic causality analysis. Renewable and Sustainable Energy Reviews, 72, 1233-1240. https://doi.org/10.1016/j.rser.2016.10.081

O'Neill, B. C., Oppenheimer, M., Warren, R., Hallegatte, S., Kopp, R. E., Pörtner, H. O., ... \& Mach, K. J. (2017). IPCC reasons for concern regarding climate change risks. Nature Climate Change, 7(1), 28. https://doi.org/10.1038/nclimate3179 
Panayotou, T. (1997). Demystifying the environmental Kuznets curve: turning a black box into a policy tool. Environment and Development Economics, 2(4), 465-484. https://doi.org/10.1017/S1355770X97000259

Perman, R., Ma, Y., McGilvray, J., \& Common, M. (2003). Natural Resource and Environmental Economics. London: Pearson Education.

Pesaran, M. H., Shin, Y., Smith, R. J. (2001) Bounds testing approaches to the analysis of level relationships. Journal of Applied Economics, 16(3), 289-326. https://doi.org/10.1002/jae.616

Phillips, P. C., \& Perron, P. (1988). Testing for a unit root in time series regression. Biometrika, 75(2), 335-346. https://doi.org/10.1093/biomet/75.2.335

Ramachandra, T. V., Aithal, B. H., \& Sreejith, K. (2015). GHG footprint of major cities in India. Renewable and Sustainable Energy Reviews, 44, 473-495. https://doi.org/10.1016/j.rser.2014.12.036

Ramsey, J. B. (1969). Tests for specification errors in classical linear least - squares regression analysis. Journal of the Royal Statistical Society: $\quad$ Series $\quad B \quad$ (Methodological), 31(2), $\quad 350-371$. https://doi.org/10.1111/j.2517-6161.1969.tb00796.x

Simons, A., Brew, L., Buabeng, A., \& Nador, H. (2018). Analysis of Carbon Dioxide Emissions in Ghana. Ghana Journal of Technology, 2(2), 1-6.

Sokolov, A., Paltsev, S., Chen, H., Haigh, M., Prinn, R., \& Monier, E. (2017). Climate Stabilization at 2 C and Net Zero Carbon Emissions.

Thampapillai, D. J., \& Ruth, M. (2019). Environmental Economics: Concepts, Methods and Policies. London: Routledge. https://doi.org/10.4324/9781315163246

Tiwari, S., Srivastava, A. K., \& Singh, A. K. (2013). Heterogeneity in pre-monsoon aerosol characteristics over the Indo-Gangetic Basin. Atmospheric Environment, 77, 738-747. https://doi.org/10.1016/j.atmosenv.2013.05.035

Twerefou, D. K., Appiah-Konadu, P., \& Anaman, K. A. (2015). Impact of international trade on the quality of the natural environment: a case study of Ghana from 1970 to 2000. Ghana Social Science Journal, 12(1), 1-21.

World Bank (2019). World Development Indicators. Washington, D.C.: World Bank, accessed 1 October 2019.

\section{Copyrights}

Copyright for this article is retained by the author(s), with first publication rights granted to the journal.

This is an open-access article distributed under the terms and conditions of the Creative Commons Attribution license which permits unrestricted use, distribution, and reproduction in any medium, provided the original work is properly cited. 